\title{
New species of short range endemic troglobitic silverfish (Zygentoma: Nicoletiidae) from subterranean habitats in Western Australia's semi-arid Pilbara region
}

\author{
Graeme B. Smith', Stefan M. Eberhard², Giulia Perina ${ }^{2}$ and Terrie Finston ${ }^{3}$ \\ ${ }^{1}$ Australian Museum, 6 College St, Sydney, New South Wales 2010, Australia.
Email: le gbsmith@optusnet.com.au.Author for correspondence. \\ 2 Subterranean Ecology Pty Ltd, Suite 8, 37 Cedric Street, Stirling, Western Australia 6021, Australia. \\ Email: info@subterraneanecology.com.au \\ ${ }^{3}$ School of Animal Biology, University of Western Australia, 35 Stirling Highway, Crawley, \\ Western Australia 6009, Australia. Email: terrie.finston@uwa.edu.au
}

\begin{abstract}
Two new troglobitic species of silverfish of the genus Trinemura Silvestri are described from the semi-arid Pilbara region of Western Australia. A third species is recorded but not described due to the lack of a mature male specimen. The deep subterranean habitat of these new species is developed within weathered rocks of banded iron formation. The surveyed distributions of each species appears confined to proximal landforms which are topographically and geologically isolated from each other. Molecular genetic evidence (12S) supports the morphological definition and phylogeographic separation.
\end{abstract}

KEYWORDS: hypogean, troglobite, iron ore formations

\section{INTRODUCTION}

Silverfish of the family Nicoletiidae are generally collected in caves and other soil-related habitats such as under stones or logs; they are primitively eyeless and generally lack pigmentation. Smith (1998) reviewed the Australian nicoletiid fauna which now comprises 14 named species in three genera, Trinemura Silvestri, 1908 (four species); Metrinura Mendes, 1994 (six species); Subtrinemura Smith, 1998 (four species), finding that species could only confidently be identified morphologically based on the secondary sexual characteristics of mature males. Some species such as Nicoletia phytophila Gervais, 1844, however, are able to reproduce parthenogenetically (Picchi 1972) and populations known only from females are not uncommon. Cave dwelling representatives are known in each genus: T. troglophila Smith, 1998 (Cape Range karst, Western Australia) and Trinemura sp. (Bat Caves, Alice Springs, Northern Territory), S. anemone (Smith, 1988) (Bungonia karst, New South Wales) and S. spelaea Smith, 1998 (Kangaroo Island karst, South Australia), M. russendenensis (Smith and Shipp, 1977) (Texas karst, Queensland), Metrinura sp. (Chillagoe karst, Queensland) (Smith 1998) and M. subtropica Smith, 2006 (Undara lava tubes, Queensland) (Smith
2006). The remaining named species are recorded from endogean habitats.

Subterranean invertebrates that are restricted to hypogean environments such as caves are classified as troglobites. They typically possess character traits related to subterranean existence (troglomorphisms) such as reduction to loss of eyes and dark pigmentation, elongation of body, legs, antennae and enhancement of non-optic sensory structures (e.g. Camacho 1992; Trajano 2005). Distinguishing troglobitic nicoletiids is complicated by the eyeless and depigmented characters exhibited by the family. Nicoletiids adapted to a strictly hypogean existence are characterised by elongated body and appendages, and increased body size, whereas endogean forms are more robust with relatively shorter appendages.

Historically, most troglobites have been collected from caves developed in carbonate rocks such as limestone and dolomite. Such karst terrains tend to be hydrogeologically discontinuous and 'patchy' at a range of spatial scales, so a high proportion of troglobitic species exhibit naturally small distribution ranges (e.g. Gibert and Deharveng 2002). Species with naturally small distribution ranges, whether they are hypogean, endogean or epigean, are often referred to as 'short- 
range endemic' (SRE) species, or alternatively 'rangerestricted' or 'narrow-range' species (Harvey 2002). Because of their small range and typically poor dispersal powers, SRE species are vulnerable to extinction from habitat loss, habitat degradation, and climate change (Harvey et al. 2011).

Arid and semi-arid environments have traditionally been considered poor prospects for sustaining moisturedependent subterranean fauna, however this view has been overturned with the discovery of diverse aquatic (stygobite) and terrestrial (troglobite) invertebrate assemblages in arid and semi-arid regions of Western Australia (see for e.g. Harvey et al. 2011; Humphreys 2008; Eberhard et al. 2005; Guzik et al. 2010). These discoveries commenced in caves of the Cape Range and Barrow Island karsts, but have since extended to encompass many other locations throughout the Pilbara and Yilgarn regions (Figure 1). Contrasting with most other recognised global hotspots of subterranean diversity, which are predominately confined to areas of karstic carbonate rocks, much of Western Australia's subterranean diversity has been found in non-carbonate, iron ore bearing rocks which do not generally develop caves large enough to be entered by humans. This hidden component of subterranean diversity has recently been revealed through sampling of mineral exploration holes and water bores which are drilled by mining and water resources development companies. Most taxonomic groups recently collected are dominated by new taxa which are so far only recognised as putative morpho species and/or DNA haplotypes. The paucity of a taxonomic framework combined with inherently patchy sampling effort and incomplete understanding of distribution ranges, poses a significant challenge to conservation and environmental impact assessment for resources development (Harvey et al. 2011).

This paper is an initial contribution towards overcoming the taxonomic impediment by describing two new large species of troglobitic silverfish collected from hypogean habitats in iron ore bearing rocks of Western Australia's arid Pilbara region. The collections included mature males as well as females and juveniles and their morphology is here described and the species named. A third smaller species, collected jointly with one of the large species, was represented by a female with a well developed ovipositor and two males which, although of similar or larger head width, did not display any secondary sexual modifications and hence could not be reliably described.

\section{MATERIALS AND METHODS}

\section{ABBREVIATIONS}

I-X abdominal segments from anterior to posterior are numbered with roman numerals

bp base pairs

EPA

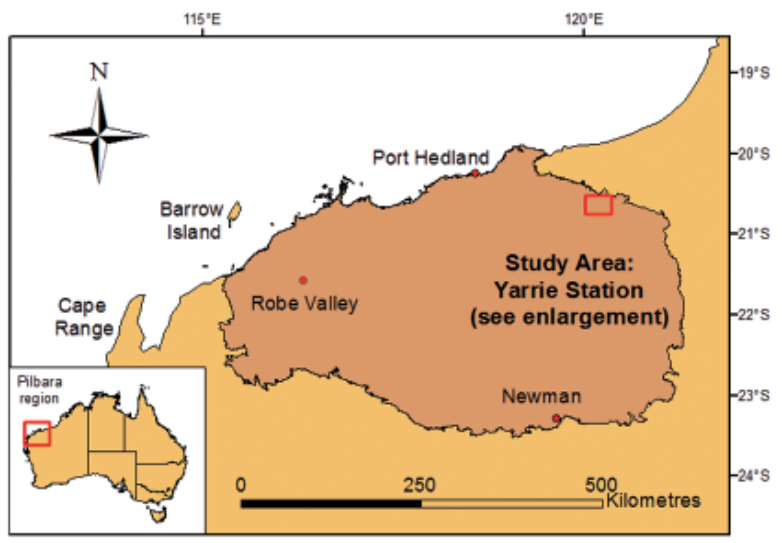

FIGURE 1 Study area (Yarrie Station) in the Pilbara IBRA region of Western Australia.

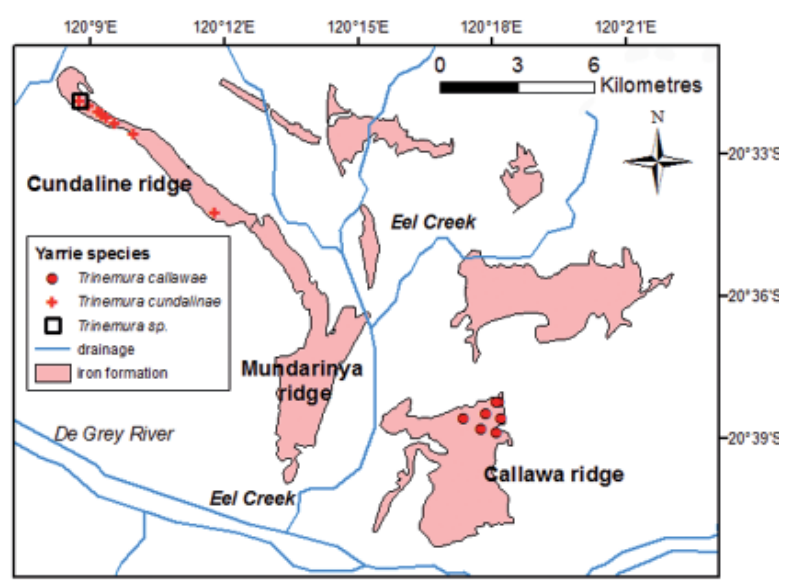

FIGURE 2 Study area on Yarrie Station showing elevated ridges and plateaux of iron-ore formation, surface drainage and collection sites for Trinemura species on Cundaline and Callawa ridges which are topographically separated by the valley of Eel Creek.

HW head width (always in millimetres)

$\mathrm{H}+\mathrm{B} \quad$ head and body length

IBRA Interim Biogeographic Region of Australia

Juv. juvenile

$\mathrm{L} / \mathrm{W} \quad$ length to width ratio

PI, PII, PIII prothoracic, mesothoracic and metathoracic legs respectively

PVC polyvinyl chloride

SRE short range endemic

\section{STUDY AREA}

The Pilbara IBRA $\left(20-24^{\circ} \mathrm{S}\right.$ and $\left.115-122^{\circ} \mathrm{E}\right)$ covers an area of approximately $178,000 \mathrm{~km}^{2}$ in the arid northwest of Western Australia (Environment Australia 2000) (Figure 1). The climate of the Pilbara region is 
Subtropical Dry, characterised by very low rainfall, high daytime temperature in summer and low winter minima (Gentilli 1972). Mean annual rainfall across the region ranges between 200 and $350 \mathrm{~mm}$ (mostly in summer), with high interannual variation associated with irregular tropical cyclones. Annual pan evaporation varies from $3200 \mathrm{~mm}$ near the coast to $>4000 \mathrm{~mm}$ inland (Bureau of Meteorology 1977).

The study area is located in the Goldsworthy Mining Operation on Yarrie pastoral station within the catchment of the De Grey River, some $180 \mathrm{~km}$ east of Port Hedland (Figure 1). The physiography of the study area is dominated by a series of ridges and plateaux landforms rising $150 \mathrm{~m}$ above the surrounding plains and alluvial valleys on the northern flank of the De Grey River. The geology of the ridges and plateaux landforms consists of Archaean-aged banded iron formation of the Nimingarra Iron Formation which is mineralised, fractured and strongly weathered (Williams 2003). The iron formation has a well developed secondary porosity associated with hematite ore-bodies that have developed within the iron formation horizons which form the prominent ridges and plateaux (BHP Billiton 2008). This study is focused on a subseries of topographically isolated ridges lying within the catchment of Eel Creek and neighbouring tributaries which flow into the De Grey River (Figure 2).

Cundaline ridge is an elongate landform approximately $1 \mathrm{~km}$ wide and $10 \mathrm{~km}$ in length. It is topographically connected to Mundarinya Ridge, which is approximately $10 \mathrm{~km}$ in length and up to $3.5 \mathrm{~km}$ wide. Callawa ridge is a rectangular-shaped landform approximately $5 \times 6 \mathrm{~km}$ in area. It is topographically separated from Cundaline-Mundarinya ridge by the valley of Eel Creek (Figure 3).

The top of the Callawa and Cundaline ridges are perforated by many mineral exploration drill holes up to 160 meters deep, which provided the access points for sampling subterranean fauna. The local water table, which lies between 60 and $120 \mathrm{~m}$ below the ridge tops, is much higher than beneath the surrounding plains owing to limited hydraulic connection between the ridge aquifers and the surrounding alluvial plain aquifers. The ridges and plains are underlain by basalts and granitoid rocks. The ridge aquifers are recharged solely by direct local rainfall infiltration. The vegetation on the ridges and plains is dominated by Spinifex grassland with sparse shrubs (including Acacia) and small trees (Eucalyptus sp.) (Figure 3).

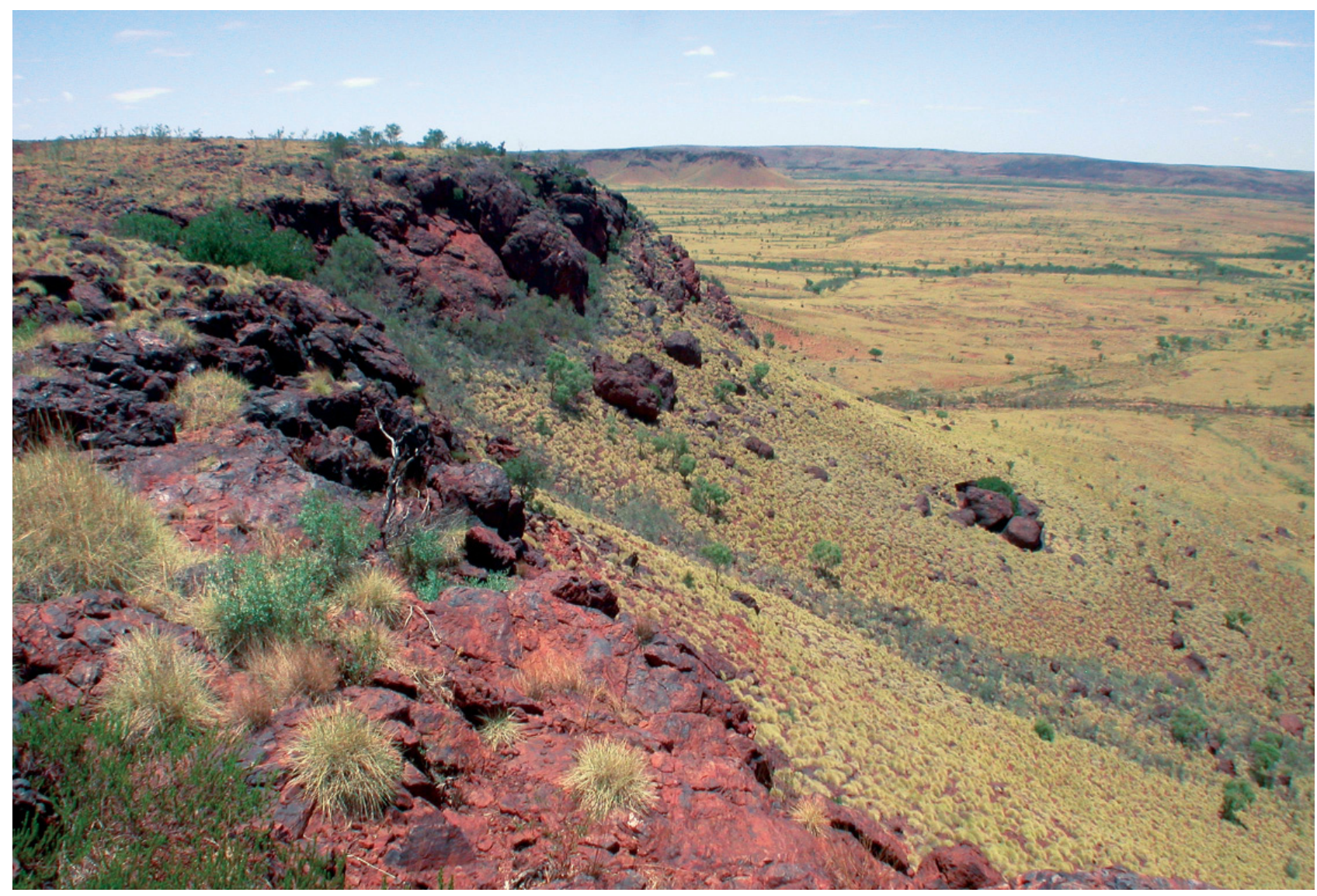

FIGURE 3 Callawa Ridge near type locality for Trinemura callawae showing elevated ridges of Nimingarra Iron Formation sparsely vegetated with Spinifex grassland. View northeast shows the alluvial valley of Eel Creek and Mundarinya-Cundaline Ridge in the distance. 


\section{COLLECTION METHODS}

Surveys of subterranean fauna at Cundaline and Callawa were conducted between 2007 and 2009 as a part of BHP Billiton's extensions to its Goldsworthy Iron Ore Mining Operations (Environmental Protection Authority 2009; Karanovic et al. 2011; Subterranean Ecology 2008a, 2008b, 2009). Terrestrial invertebrates were collected from mineral exploration drill holes by a combination of litter traps and net haul / scraping methods, both are standard approaches used in subterranean fauna surveys in Western Australia. Litter traps were constructed of $55 \mathrm{~mm}$ diameter PVC pipe cut to a length of $140 \mathrm{~mm}$. The top of the trap consisted of $10 \mathrm{~mm}$ aviary mesh to allow invertebrates to enter the trap, the bottom was sealed with a PVC cap with a small hole to allow excess moisture to drain. Traps were loosely filled with leaf litter derived from native vegetation. The leaf litter was sterilised by heating in a microwave for 10 minutes on high power. The litter traps, attached to $2 \mathrm{~mm}$ diameter venetian blind cord, were then lowered into vertical or inclined drill holes to a depth of approximately 20 metres below the surface. The cord was tied off at the surface and the drill holes capped with a concrete plug. Litter traps were left in place for at least six weeks to allow time for colonisation by invertebrates, then retrieved and sealed in zip-lock plastic bags for transport to the laboratory, where the fauna were extracted using Tullgren funnels, and preserved in $100 \%$ ethanol.

The scraping method is based on the net haul method used to collect stygofauna (Environmental Protection Authority 2007). It involves a plankton net $(150 \mu \mathrm{m}$ mesh) of an appropriate diameter approximating twothirds of the drill hole diameter (generally 80-100 mm). The net with a weighted vial attached was lowered to the base of the drill hole, or one metre below the water surface in wet holes), and hauled up in a manner that maximised contact with the wall surface, with the aim of dislodging and collecting invertebrates. This process was repeated four or six times per drill hole with the aim of sampling each side of the hole. Scrape samples were elutriated on site, preserved in 100\% ethanol, labelled and sealed in a $30 \mathrm{ml}$ vial for transport to the laboratory for sorting and identification.

\section{SPECIMEN PREPARATION}

A series of measurements of all specimens was undertaken according to the method described in Smith (1998) where data for other Australian members of the genus can also be found. All silverfish specimens collected during this survey have been deposited with the Western Australian Museum, Perth. Unless specified as being mounted on slides, all specimens are stored individually in 80 or $100 \%$ ethanol.

Silverfish in general are soft bodied and very fragile and difficult to collect and preserve in good condition. Subterranean collections are even more difficult as the insects are usually much less robust; setae and appendages, especially the terminal filaments are easily lost or damaged with repeated handling. Ideally specimens should be dissected and slide material prepared as soon as possible to minimise further deterioration. Furthermore specimens often get covered in a fine dust during the collection process hindering observation of critical morphological features such as the secondary sexual characters at the base of the terminal filaments.

Silverfish were dissected under an Olympus SZ61 stereomicroscope and drawings made with the aid of an Olympus CX31 binocular microscope fitted with a U-DA drawing attachment. Tendeiro solution was used for the preparation of slide material as the specimens can be dissected in 100\% ethanol and transferred directly into the mounting medium. However this standard procedure encountered an unexpected problem where the larger setae were found to deform in the Tendeiro solution within a week of preparation; they twisted and their surfaces developed ridges. This had not been seen with any other silverfish species mounted to that date in the same medium. A series of evaluations using readily available Australiatelura specimens (Zygentoma: Ateluridae) including fresh Tendeiro solution, different drying temperatures and durations failed to reproduce the problem. No problems were seen when preparing slides of various lepismatid silverfish species (Xenolepisma penangi, 3 species of Heterolepisma and 2 species of Ctenolepisma) but the issue recurred (to a lesser extent) with more recent Cundaline material dried at cool room temperature $\left(<20^{\circ} \mathrm{C}\right)$. It would appear that there is some interaction of the Tendeiro solution with the surface of the macrochaetae of both these large species of Trinemura.

\section{MOLECULAR ANALYSIS}

Six specimens of Zygentoma from Cundaline and Callawa (WAM E82742, WAM E82749, WAM E82750, WAM E82751, WAM E82753, WAM E82755) were sequenced for variation at the mitochondrial small ribosomal RNA gene (12S) using the primers SR-N14588 and SR-J-14233 or primers LR-J-13331 and SR-N-14588 (Simon et al. 1994; Genbank accession \#s JQ282160-JQ282165). No specimen of the small Trinemura sp. was available when the sequencing was conducted.

Sequences were edited using SEQUENCHER software (Gene Codes Corporation, Ann Arbor, MI, USA). Alignment was performed with CLUSTAL W (Thompson et al. 1994) using default parameters. Genetic distances between unique genetic sequences (haplotypes) were measured using uncorrected p-distances (total percentage of nucleotides different between sequences).

\section{RESULTS}

\section{MOLECULAR ANALYSIS}

The six specimens of Zygentoma were sequenced for 
TABLE 1 Pair-wise 12S sequence divergence (below diagonal) between specimens of Zygentoma. The standard error is shown above the diagonal (in italics). WAM E82742 is from Cundaline, the remainder from Callawa.

\begin{tabular}{lllllll} 
Specimen ID & WAM E82749 & WAM E82750 & WAM E82751 & WAM E82753 & WAM E82755 & WAM E82742 \\
\hline WAM E82749 & & 0.000 & 0.000 & 0.003 & 0.005 & 0.013 \\
WAM E82750 & 0.000 & & 0.000 & 0.003 & 0.005 & 0.013 \\
WAM E82751 & 0.000 & 0.000 & & 0.003 & 0.005 & 0.013 \\
WAM E82753 & 0.003 & 0.003 & 0.003 & & 0.004 & 0.013 \\
WAM E82755 & 0.009 & 0.009 & 0.009 & 0.006 & & 0.013 \\
WAM E82742 & 0.065 & 0.065 & 0.065 & 0.062 & 0.062 & \\
\hline
\end{tabular}

a 350-397 bp fragment of the $12 \mathrm{~S}$ gene. There were four unique DNA sequences (= haplotypes) among the six specimens, with the three specimens from bore CA0006 sharing the same haplotype. The three haplotypes of Zygentoma from Callawa differed from one another by between 0.3 and $0.9 \%$ sequence divergence (Table 1). The haplotype of Zygentoma from Cundaline differed from the Callawa haplotypes by between 6.2 and $6.5 \%$ sequence divergence (Table 1).

\section{SYSTEMATICS}

\section{Family Nicoletiidae Escherich, 1905}

\section{Subfamily Subnicoletiinae Mendes, 1988}

\section{Trinemura Silvestri, 1908}

Trinemura Silvestri, 1908: 61.

\section{TYPE SPECIES}

Trinemura novaehollandiae Silvestri, 1908 by monotypy.

\section{Trinemura callawae sp. nov.}

urn:Isid:zoobank.org:pub:0C4AC372-9BB5-46A79635-608E7CC7430D

Figures 4-30

\section{MATERIAL EXAMINED}

\section{Holotype}

Australia: Western Australia: $\widehat{\jmath}$ (HW 1.30), Yarrie Station, Callawa (CA0144-seLN1020) (20³8'19"S, $120^{\circ} 18^{\prime} 19^{\prime \prime}$ E), P. Bell and S. Eberhard, 16 December 2007, scrape method; dissected and mounted on three microscope slides (WAM E82755) Genbank accession \#JQ282164.

\section{Paratypes}

Australia: Western Australia: $1 \hat{\jmath}$ (HW 1.13), Yarrie Station, Callawa (CA0006-seLN6122) (20³8'40"S, $\left.120^{\circ} 18^{\prime} 23^{\prime \prime} \mathrm{E}\right)$, P. Bell and K. Muirhead, 29 July 2008, scrape method; leg and antenna on slide, remainder in alcohol (WAM E82749) Genbank accession \#JQ282160; 2 (both with HW 1.13), same collection data as above (WAM E82750, WAM E82751) Genbank accession \#JQ282162 and \#JQ282161; 1 q (HW 1.00, Yarrie Station, Callawa (CA0124-seLN2272) (20³8'53"S, $\left.120^{\circ} 17^{\prime} 57^{\prime \prime E}\right)$, P. Bell and D. Eberhard, 25 April 2008, scrape method (WAM E82753) Genbank accession \#JQ282163; 1 juv. స̂ (HW 0.63 Yarrie, Callawa (CA0011-seLN2287) (20³8'57"S, 120¹8'17"E), P. Bell and D. Eberhard, 26 April 2008, scrape method (WAM E82752); 1 juv. \& (HW 0.71) Yarrie Station, Callawa (CA0011-LN6448) (20³8'57"S, 120¹8'17"E) P. Bell, 31 May 2009, scrape method (WAM E82703); 1 juv. $\sigma^{\lambda}$ (HW 0.73) Yarrie Station, Callawa (CA0011-LN6448) (20³8'57"S, 120¹8'17"E) P. Bell, 31 May 2009, scrape method (WAM E82704); 1 + (HW 1.23) Yarrie Station, Callawa (CA0124-LN6883) (20³8'53"S, 120¹7'57"E) P. Bell, 14 June 2009, scrape method (WAM E82705); 1 సै (HW 1.33) Yarrie Station, Callawa (CA0099-LN6945) (203' $40^{\prime \prime}$ S, $\left.120^{\circ} 17^{\prime} 32^{\prime \prime E}\right)$ P. Bell, 10 July 2009, scrape method (WAM E82706); 1 juv. ठิ (HW 0.88) Yarrie Station, Callawa (CA0009-LN6441) (20³8'34"S, $\left.120^{\circ} 18^{\prime} 02^{\prime \prime E}\right)$ P. Bell, 31 May 2009, scrape method (WAM E82707).

\section{DIAGNOSIS}

This species is distinguished from congeners by its large size, the form of the apophyses on the pedicel and scape as well as the short rows of modified setae on both the cerci and median dorsal appendage of mature males.

\section{DESCRIPTION}

Adults

Quite large species, $\mathrm{H}+\mathrm{B}$ in preserved specimens examined up to $13.10 \mathrm{~mm}$ (HW 1.33) but all are quite distended and a graphical "reconstruction" of the 
specimen whereby the tergites are positioned so that the intersegmental membranes are just hidden (Figure 4) suggests a total length in live specimens of $10.7 \mathrm{~mm}$, thorax length $3.35 \mathrm{~mm}$ or about one third $\mathrm{H}+\mathrm{B}$ and width $1.95 \mathrm{~mm}$; antennae broken in all specimens but at least greater than $\mathrm{H}+\mathrm{B}$; caudal filaments broken in all specimens.

Head and body lacking scales but covered in scattered fine hyaline setae, as well as some stronger setae on the disc and margins and quite robust, sometimes apically minutely bifurcated, macrochaetae on the margins. Hypodermal pigment lacking; colour probably white but the specimens covered with film of fine reddish dust, making them appear darker.

Head: wider than long, with several strong macrochaetae along the anterior lateral margins above the antennae as well as stronger macrochaetae in the posterior lateral corners as in Figure 5. Antennae elongate; scape of $\hat{\sigma}$ with strong distal apophysis directed ventrally (Figure 6); pedicel of $\bar{\partial}$ with two apophyses ventrally (Figure 7), the most proximal apophysis thumb-like and somewhat sclerotised, arising from the centre of a rosette of glands and the other longitudinally broad with numerous glands on the outer face; third article with several trichobothria (Figures 6, 7); most distal preserved subarticles (Figure 8) subequal, slightly longer than wide, articles in distal half of preserved part of antenna lacking trichobothria, next quarter with one trichobothria per four subarticles, next eighth with one trichobothria per two subarticles, with articles in basal eighth indistinct (much wider than long) with two trichobothria per article. Labrum and clypeus normal for genus (Figure 5), mandibles (Figure 9) strong with well-developed molar region, maxillae (Figure 10) of usual form, galea equal in length to lacinia with two apical cones that extend beyond the lacinia, pectinate process (Figure 11) short, maxillary palp (Figure 10) very long in mature specimens with the ultimate article about one third longer than the penultimate and both articles about four times longer than wide, in juvenile specimens these articles are only about two and a half times as long as wide, second article with subapical ring of strong apically bifurcate setae, third article subapically with a few strong apically bifurcate setae (Figure 12), ultimate article with six papillae of usual form (Figure 13). Labium (Figure 14) very long with elongate palp whose penultimate article is twice as long as wide, ultimate article with six papillae of usual type.

Thorax: prothorax with obvious setal collar, all nota with some strong apically bifurcate macrochaetae near lateral margins, posterior and lateral margins with both strong macrochaetae and smaller setae, disc of nota with some stronger setae among the hyaline setae (Figures 15-17). Legs mostly missing from specimens, quite elongate (Figures 18, 20); femur with three strong subapical spines and a pair of long macrochaetae and sometimes a single more proximal macrochaeta on the ventral margin, tibia with several strong macrochaetae on ventral margin and one or two strong macrochaetae distally near the dorsal margin, tarsus with four articles the basal one being almost as long as the other three together, pretarsus (Figure 19) with two strong claws with small medial empodial claw; meso and meta tarsi more than 10 times longer than wide, tibia three to four times longer than wide.

Abdomen: Abdominal tergites (Figure 21) with macrochaetae along posterior margins and some stronger setae among hyaline setae on disc, suture with paratergites faintly visible on slide material. Urotergite $\mathrm{X}$ with shallow posterior emargination with two longer and one shorter macrochaetae at each of the apical angles and between these 1+1 longer setae as well as smaller setae over the disc and along the margins (Figure 22).

All urosternites entire (not divided into median sternite and 1+1 lateral coxites), urosternite I without stronger setae; urosternites II-VIII with 1+1 submarginal, erect, apically bifurcated macrochaetae submedially as well as several setae along posterior margins (Figure 23); urosternites III-IX with stylets, apical spine of stylets with irregular shape (Figures. 24), stylets IX slightly longer than others, eversible vesicles lacking, pseudovesicles on urosternite VII; urosternite IX with shallow emargination and a few stronger setae in indistinct submarginal row; parameres of male (Figures 25, 26) with eversible tips, the basal region only just extending beyond the short, acute internal processes of urosternite IX, the eversible portion extending beyond these processes.

Appendix dorsalis of $\hat{\sigma}$ basally with some strong modified spines ventro-laterally (Figure 27), one or two on each side of basal article, $1+1$ on short second article and $2+2$ on third and fourth articles; cerci (Figures 28, 29 ) with two to three short modified spines on mediad ventral aspect of basal article and four to six on the very long second article, macrochaetae on subsequent articles in same position not so obviously modified and becoming less so distally.

\section{Female}

As for male except pedicel and scape without apophyses; caudal appendages lacking modified setae; ovipositor pseudoarticulated (Figure 30) relatively short, not extending beyond apices of urostylets IX in largest female (WAM E82705 HW 1.23), consisting of eight articles in specimens examined. Subgenital plate long, narrow and rounded.

\section{Juveniles}

Stylets fully developed on all abdominal segments even in smallest individual (WAM E82752 HW 0.63)

\section{ETYMOLOGY}

In view of the likely restricted distribution range of this and the following species, the species' names of both are derived from the Latinised names of the landforms from where they were collected. 


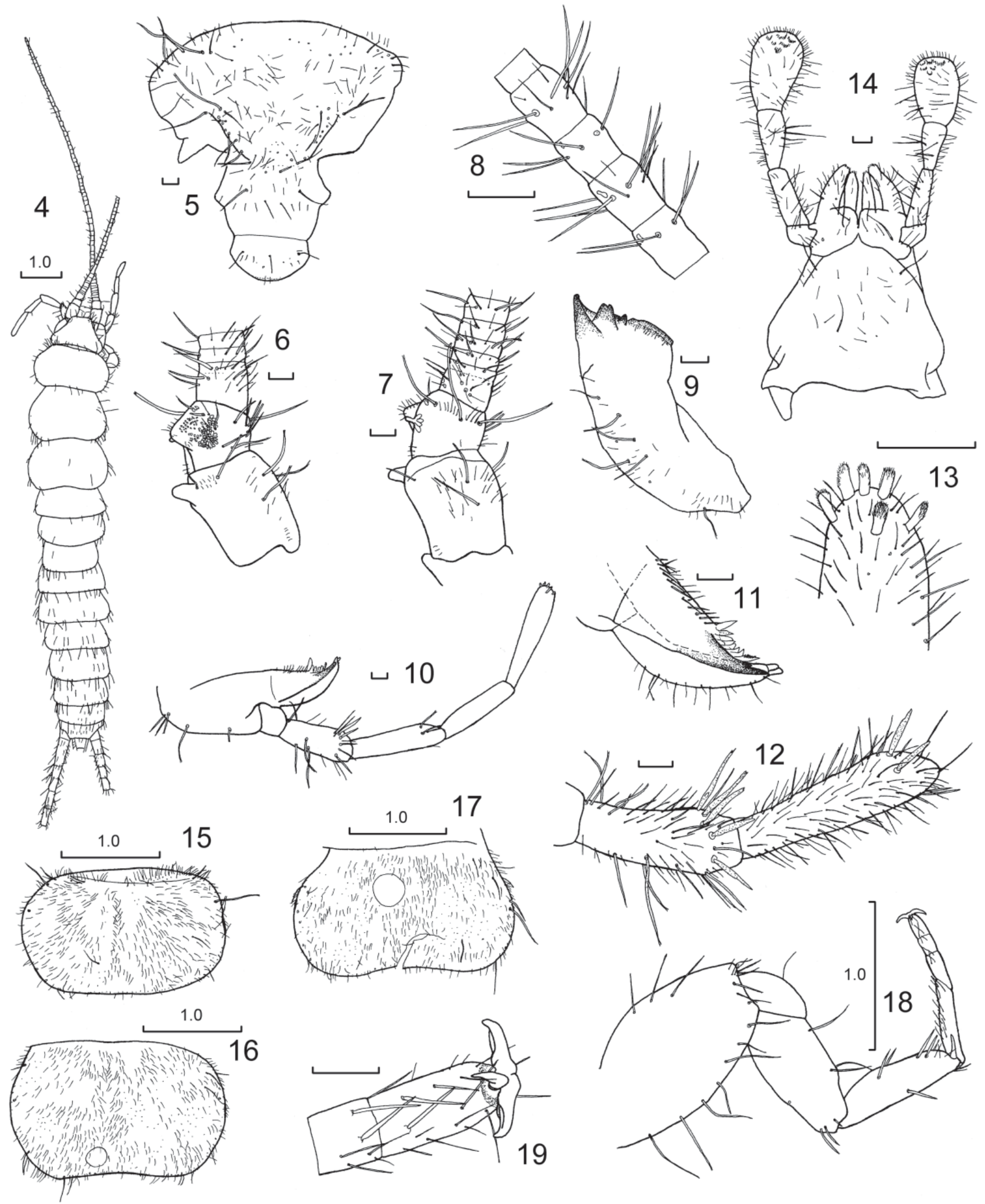

FIGURES 4-19

Trinemura callawae sp. nov., holotype ô (WAM E82755) unless stated otherwise: 4, habitus; 5 , head; 6, right pedicel, internal lateral view; 7, left pedicel, external lateral view; 8, most apical section of antenna; 9, mandible; 10, maxilla (only major setae shown); 11, maxilla, detail of galea and lacinia; 12, maxillary palp, chaetotaxy of articles two and three; 13, maxillary palp, detail of apex of ultimate article; 14, labium; 15, pronotum; 16, mesonotum; 17, metanotum, circular area is air bubble obscuring view; 18, PII (WAM E82749); 19, same, detail of pretarsus. All scale bars $0.1 \mathrm{~mm}$ unless otherwise indicated. 

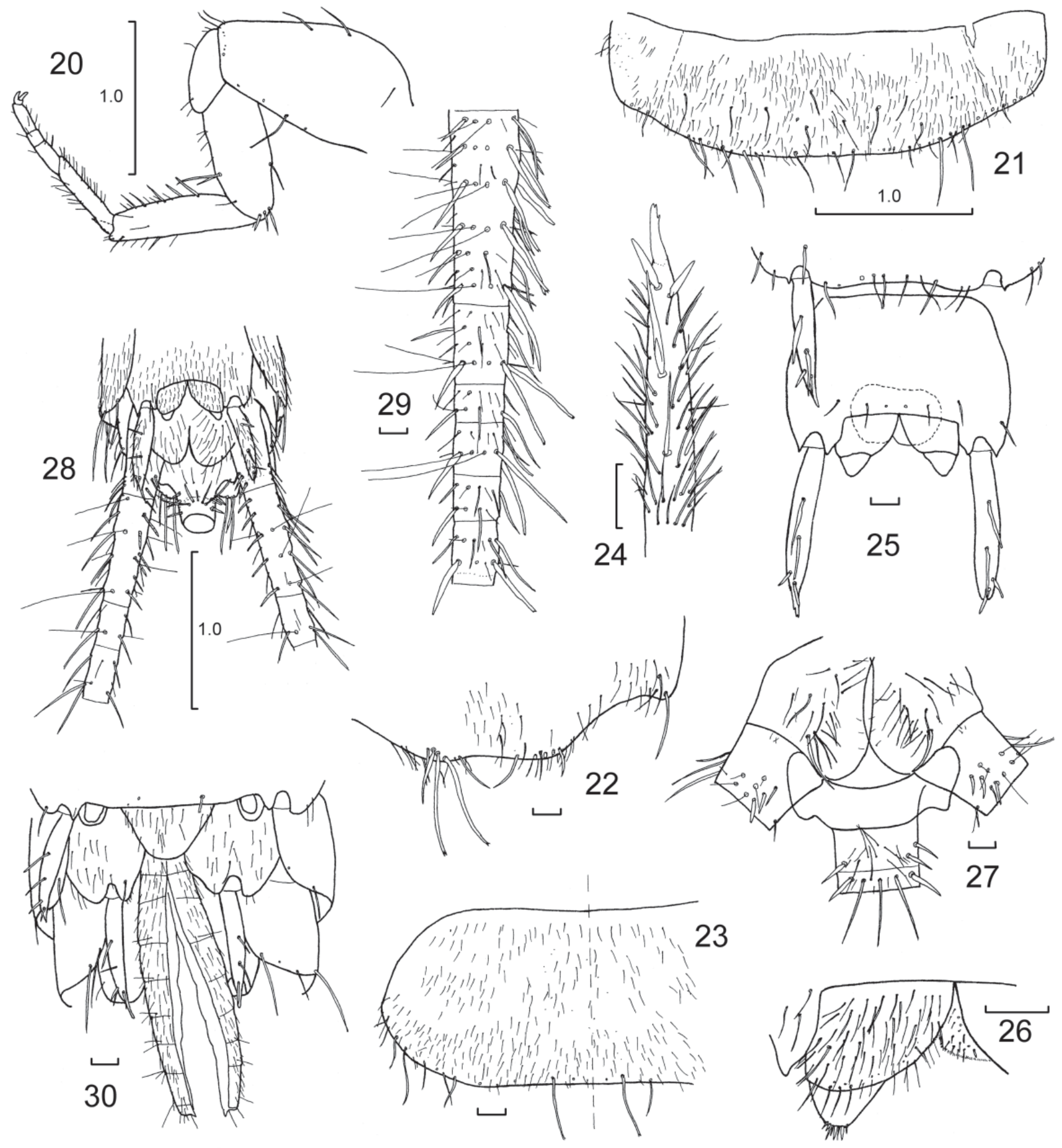

FIGURES 20-30 Trinemura callawae, sp. nov., holotype $\lesssim$ (WAM E82755) unless stated otherwise: 20, PI; 21, urotergite IV; 22, urotergite $X ; 23$, urosternite II, showing submedial erect apically bifurcated macrochaetae; 24, stylet IV; 25, urosternites VIII and IX; 26, paramere; 27, base of terminal filaments; 28, genital region and base of terminal filaments; 29, articles from second of cerci; 30, genital region and ovipositor of + (WAM E82753). All scale bars $0.1 \mathrm{~mm}$ unless otherwise indicated. 
Trinemura cundalinae sp. nov.

\author{
urn:Isid:zoobank.org:pub:0C4AC372-9BB5-46A7- \\ 9635-608E7CC7430D
}

Figures 31-54

\section{MATERIAL EXAMINED}

\section{Holotype}

Australia: Western Australia: $\hat{\sigma}$ (HW 1.26) Yarrie Station, Cundaline (CU0058-LN7008) (20³2'22"S, $\left.120^{\circ} 9^{\prime} 12^{\prime \prime} \mathrm{E}\right)$, P. Bell, 27 July 2009, scrape method (WAM E82692) on 2 slides (head and thorax, abdomen)

\section{Paratypes}

Australia: Western Australia: 1 (HW $1.13 \mathrm{~mm})$, Yarrie Station, Cundaline (CU0060R-seLN1093) $\left(20^{\circ} 32^{\prime} 26^{\prime \prime} \mathrm{S}, 120^{\circ} 09^{\prime} 18^{\prime \prime} \mathrm{E}\right), \mathrm{P}$. Bell and S. Eberhard, 18 December 2007, scrape method (WAM E82742) Genbank accession \#JQ282165; 1 ( $\mathrm{HW}$ 1.05) Yarrie Station, Cundaline (CU0062-seLN1248) (20³2'29"S, $120^{\circ} 09^{\prime} 24^{\prime \prime}$ ), P. Bell and S. Eberhard, 15 December 2007, scrape method (WAM E82743), in very poor condition; 1 juv. $\widehat{\jmath}$ (HW 0.80) Yarrie Station, Cundaline (CU0058-LN7250) (20³2'22"S, 1209'12"E) P. Bell, 21 July 2009, trap method (WAM E82684); 1 juv. $\widehat{\jmath}$ (HW 0.65 ) same collection data as previous (WAM E82685); juv. $\widehat{o}$ (HW 0.70) Yarrie Station, Cundaline (CU0073LN7259) (20³4'27"S, 120¹1'53"E) P. Bell, 21 July 2009, trap method (WAM E82686); 1 juv. $\widehat{\jmath}$ (HW 0.85) Yarrie Station, Cundaline (CU0058-LN6522) (20³2'22"S, $120^{\circ} 9^{\prime} 12^{\prime \prime E}$ ) P. Bell, 29 May 2009, scrape method (WAM E82687); 1 juv. ( (HW 0.85) Yarrie Station, Cundaline (CU0070-LN6525) (20³2'10"S, 120 $\left.0^{\prime} 47^{\prime \prime E}\right)$ P. Bell, 29 May 2009, scrape method (WAM E82688); 1 juv. $\lesssim$ (HW 0.66) Yarrie Station, Cundaline (CU0046-LN6529) (20³2'37"S, 120 9'35"E) P. Bell, 29 May 2009, scrape method (WAM E82689); 1 juv. \& (HW 0.73) Yarrie Station, Cundaline (CU0046-LN6529) (20³2'37"S, $120^{\circ} 9^{\prime} 35^{\prime \prime E}$ ) P. Bell, 29 May 2009, scrape method (WAM E82690); 1 \& (HW 1.25) Yarrie Station, Cundaline (CU0057-LN7261) $\left(20^{\circ} 32^{\prime} 15^{\prime \prime} \mathrm{S}, 120^{\circ} 9^{\prime} 0.5^{\prime \prime} \mathrm{E}\right)$ P. Bell, 21 July 2009, trap method (WAM E82691); 1 juv. q (HW 0.69) Yarrie Station, Cundaline (CU0060-LN7211) (20³2'26"S, 120 9'18"E) P. Bell, 21 July 2009, scrape method (WAM E82693); 1 § (HW1.00) Yarrie Station, Cundaline (CU0285-LN6988) (20³2'49"S, 120¹0'1"E) P. Bell, 8 July 2009, scrape method (WAM E82694); 1 ( $\mathrm{HW}$ 1.30) Yarrie Station, Cundaline (CU0062LN7010) (20³2'29"S, 1209'24"E) P. Bell, 21 July 2009, scrape method (WAM E82696); 1 \% (HW 1.30) Yarrie Station, Cundaline (CU0070-LN7017) (20³2'10"S, 120 ${ }^{\circ} 47^{\prime \prime E}$ ) P. Bell, 21 May 2009 (damaged missing segments VIII-X), scrape method (WAM E82697); 1 q (HW 1.23) Yarrie Station, Cundaline (CU0063-LN7016) (20³2'25"S, 1209'19"E) P. Bell, 21 May 2009, scrape method (WAM E82701); 1 juv. $\bigcirc$ (HW 0.78) Yarrie Station, Cundaline (CU0070-LN7212) (20³2'10"S, $120^{\circ} 8^{\prime} 47^{\prime \prime E}$ ) P. Bell, 29 May 2009, scrape method (WAM E82702).

\section{DIAGNOSIS}

Mature males of this species can be distinguished from congeners by their large size, the form of the apophyses on the pedicel and scape, the short modified setae on both the cerci and median dorsal appendage and the anemone structures on the cerci and adjacent basal integument. The macrochaetae of the legs are noticeably shorter and thicker than those of Trinemura callawae in both sexes.

\section{DESCRIPTION}

\section{Adults}

Quite large species (Figure 31), H+B in non-distended preserved specimens up to $10.9 \mathrm{~mm}$ (HW 1.13 but in specimens that have become distended can reach $14.6 \mathrm{~mm}$ (HW 1.30), thorax length $3.18 \mathrm{~mm}$ (4.28 in distended specimen) and width $1.83 \mathrm{~mm}$ or about one third $\mathrm{H}+\mathrm{B}$; antennae broken in all specimens, longest preserved antenna 1.16 times $\mathrm{H}+\mathrm{B}$; caudal filaments broken in all specimens, longest preserved cerci 0.28 times $\mathrm{H}+\mathrm{B}$.

Head and body lacking scales but covered in scattered fine hyaline setae, and a few stronger setae on the disc and margins of the tergites as well as quite robust, sometimes minutely apically bifurcated, macrochaetae on the margins of most sclerites. Hypodermal pigment lacking; colour probably white but specimens covered with film of fine reddish dust, making them appear darker.

Head: wider than long, with several strong macrochaetae along the anterior lateral margins above the antennae (Figures 32, 33) as well as stronger macrochaetae in the posterior lateral corners. Antennae scape of $\hat{\delta}$ with a strong distal, slightly hooked apophysis directed ventrally, its apex turned slightly mediad (Figure 34), pedicel of $\delta$ (Figures 32, 34) swollen ventrally and medially, outer side with subtriangular blade-like process directed ventrally with a rosette of glands at its base on the external side and another on the internal side more distally, outer face with numerous subcircular glands; inner side with line of several setae; third article with several trichobothria above and below, subsequent articles with two trichobothria (Figures 33, 34); more distal articles unclearly subdivided (Figure 35), most distally preserved subarticles (Figure 36) subequal, slightly longer than wide, apparently lacking trichobothria. Labrum and clypeus normal for genus (Figure 32), mandibles (Figure 37) with small and unusually smooth molar region (not showing obvious ridges) but rougher texture than strong incisors, internally with two approximate rows of short stout pointed setae, the more distal row of about 10 setae behind the molar region, the second of about 14 setae extending across whole molar region and about half of the incisor region; maxillae (Figure 38) of usual form for genus, galea equal in length to lacinia with two apical cones that extend well beyond the lacinia, pectinate process (Figure 39) short, followed by seven lamellate processes and then two 


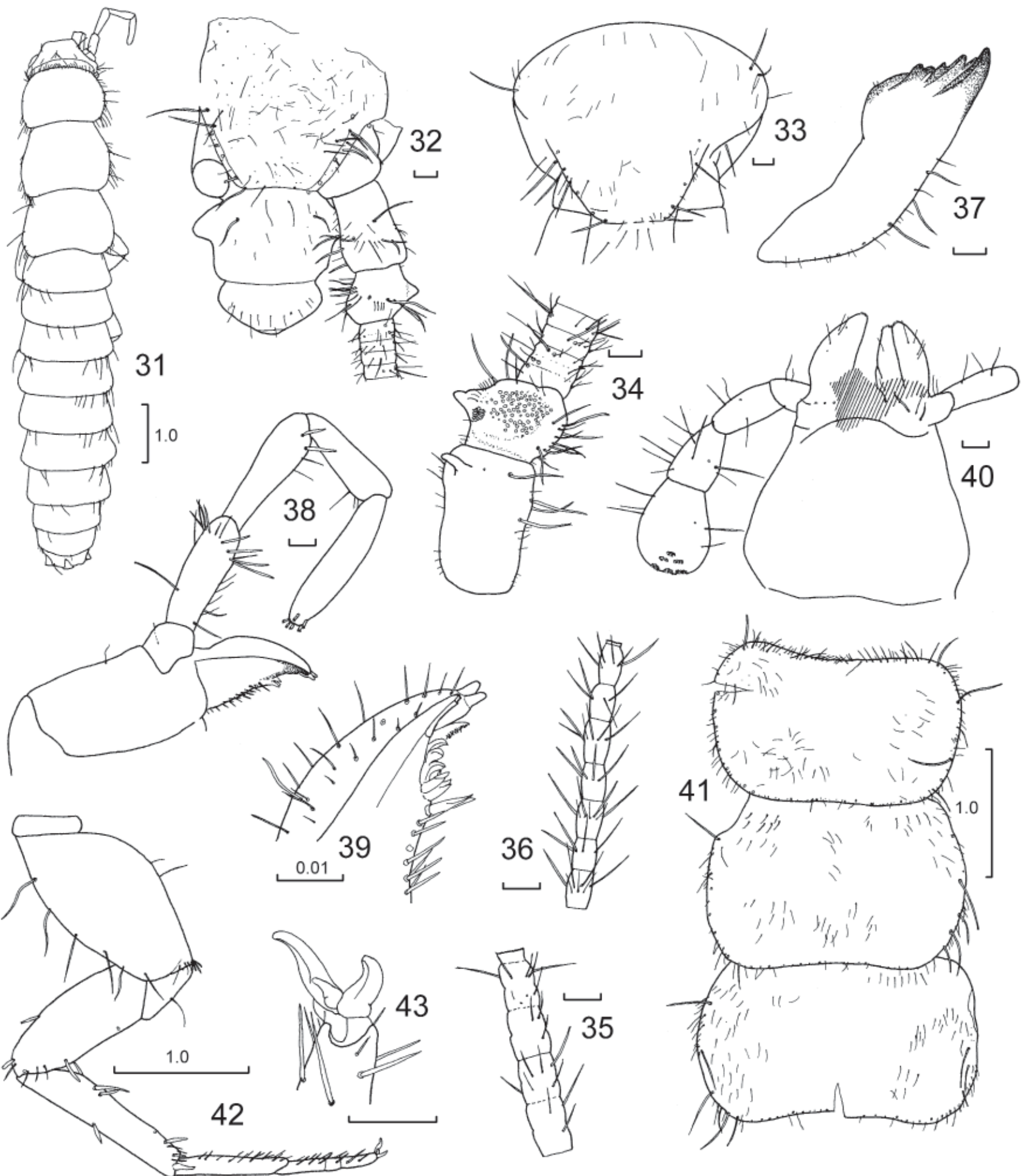

FIGURES 31-43 Trinemura cundalinae, sp. nov., holotype ô (WAM E82692) unless stated otherwise: 31, habitus; 32, head and base of left antenna; 33, head (O) (WAM E82742); 34, left pedicel, external lateral view; 35, mid section of antenna (WAM E82697); 36, most distal preserved articles (WAM E82691); 37, mandible; 38, maxilla (only major setae shown); 39, maxilla, detail of galea and lacinia; 40, labium (cross-hatched area at least partially obscured by dirt); 41, nota; 42, PIII; 43, same, detail of pretarsus. All scale bars $0.1 \mathrm{~mm}$ unless otherwise indicated. 

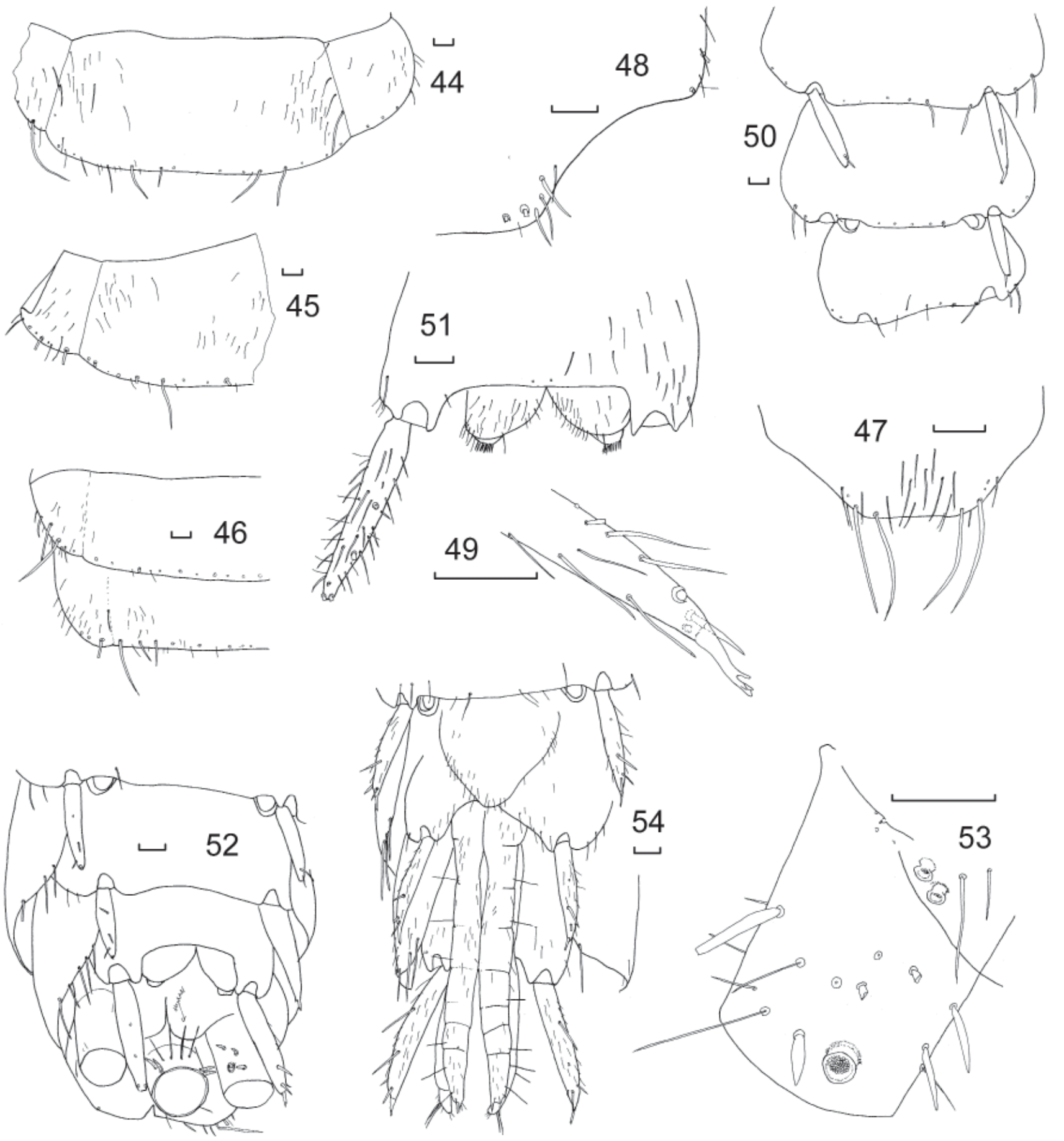

FIGURES 44-54

Trinemura cundalinae, sp. nov., holotype ô (WAM E82692) unless stated otherwise: 44, urotergite I; 45, urotergite V; 46, urotergites VIII-IX; 47, urotergite X (WAM E82684): 48, urotergite $\mathrm{X}$, right half; 49, apex of stylet of urosternite VIII; 50, urosternites VI-VIII; 51, urosternite VIII and parameres; 52, genital region, ventral aspect; 53, enlargement of base of right cercus; 54, genital region and ovipositor of + (WAM E82742). All scale bars $0.1 \mathrm{~mm}$ unless otherwise indicated. 
parallel rows of short stout setae, maxillary palp of five articles (Figure 38), very long in mature specimens (less elongate in smaller specimens) covered in numerous fine setae, basal article very short, second article with subapical rosette of strong setae, middle article apically with two(?) stout, apically bifurcate setae, penultimate article 2.2-3.9 times longer than wide, ultimate article 1.2-1.7 times longer than the penultimate, and 3.4-6.4 times longer than wide with six apical papillae of usual form; labium (Figure 40) longer than wide, penultimate article of palp in mature specimens about one and a half times as long as wide, ultimate article slightly longer than penultimate, both of which have some very long thin setae, apical article flattened sub-ovate, 1.12-1.46 times longer than wide with six papillae of usual type.

Thorax: prothorax with obvious setal collar (Figure 41), all nota with some strong apically bifurcate macrochaetae near lateral margins, posterior and lateral margins with both long, strong simple macrochaetae and smaller setae, disc of nota without obviously stronger setae among the hyaline setae. Legs, often missing from specimens, quite elongate (Figure 42) femur with macrochaeta two thirds along dorsal margin and two stout macrochaetae and between them one thinner macrochaeta subapically and a pair of macrochaetae subdistally on the ventral margin, tibia of PIII 4.2-6.1 times longer with four to six stout macrochaetae on ventral margin and one stout macrochaetae midway along the dorsal margin as well as some small stronger macrochaetae subdistally and the usual apical spur, tarsus of PIII 10.5-14.9 times longer than wide of four articles the basal one being about as long as the other three together, pretarsus (Figure 43) with two strong claws with medial empodial claw. All macrochaetae on the femur and tibia are shorter and stouter than the equivalent macrochaetae on Trinemura callawae.

Abdomen: Abdominal tergites (Figures 44 to 46) with several long submarginal macrochaetae along posterior margins and scattered hyaline setae on disc, some a little longer than others, suture with paratergites distinctly visible on mounted material especially on anterior segments (almost invisible on IX). Urotergite $\mathrm{X}$ with almost straight or just slightly concave posterior margin with two longer macrochaetae at each of the apical angles and a few smaller setae over the disc and along the lateral margins (Figures 47, 48).

Urosternites entire, III-IX with stylets, apical spines of stylets robust with complex branched tips (Figure 49); eversible vesicles lacking, pseudovesicles on urosternite VII (Figure 50); all urosternites with several long, acute, backwardly-directed macrochaetae along posterior margins, urosternites II (or I?)-VIII also with more pigmented 1+1 submarginal, erect, apically bifurcate macrochaetae; urosternite IX in $\hat{\sigma}$ (Figure 51) with shallow emargination (less than one quarter the length of the urosternite) and a few scattered setae; parameres (Fig 51) with eversible tips with short, pointed rod-like setae, the basal region not extending much beyond the short, acute internal processes of urosternite IX, the eversible portion extending just beyond these processes.
Caudal appendages in all specimens incomplete; mature male specimens with basal article of appendix dorsalis with three short stout modified setae (Fig 52) on each side, basal article of cerci with a glabrous anemonestructure on the mediad ventral surface along with three short modified spines; two smaller glabrous anemone structures are also present on the integument adjacent to the base of the cerci, visible only in dissected material (Figure 53). Another $\hat{\sigma}$ (WAM E82694 HW1.00) has longer sections of cerci and median dorsal appendages but these are covered with large amounts of red dust. It appears that the cerci have a series of five anemone structures, each adjacent to a modified spine, however the amount of adhered dust makes this uncertain; the modified spines do not extend very far along the cerci (not possible to count articles); there are only five to seven modified spines on the sides of the medial dorsal appendage, then reverting to more normal setae.

\section{Female}

As for male except pedicel and scape without apophyses, pedicel not enlarged; caudal appendages lacking modified setae and anemone-structures; ovipositor (Figure 54) relatively short, not extending beyond apices of urostylets IX, consisting of eight articles in specimens examined. Subgenital plate long, narrow and rounded (Figure 54).

\section{Juveniles}

All juveniles (the smallest being WAM E82685 HW 0.65 ) had the full series of stylets on urosternites IIIIX. One $\widehat{\sigma}$ (WAM E82687 HW 0.85) was beginning to show the first signs of secondary sexual modification, the pedicel was beginning to swell but the apophyses had not developed, the cerci and appendix dorsalis (only basal articles present) were showing some thickened setae but anemone structures were not present. A larger స (WAM E82694 HW1.00) displayed all secondary sexual characteristics. Juvenile males with HW 0.80 or below did not show any secondary sexual character development. A $q$ of similar HW (0.85) had an ovipositor that was already reaching to half the length of the stylets on urosternite IX, whereas juvenile females with HW 0.73 had only small lumps developing on the posterior edges of urosternites VIII and IX the latter not yet reaching beyond the base of stylets IX.

\section{Trinemura sp.}

Figures 55-57

\section{MATERIAL EXAMINED}

Australia: Western Australia: 1 के (HW 0.50) Yarrie Station, Cundaline (CU0070-LN7017) (20³2'10"S, $\left.120^{\circ} 8^{\prime} 47^{\prime \prime E}\right)$, P. Bell, 21 May 2009, scrape method (WAM E82698); $1 \hat{\jmath}$ (HW 0.65) same data as above (WAM E82699); $q$ (HW 0.53) same data as above (WAM E82700).

\section{REMARKS}

Three small silverfish $(\mathrm{H}+\mathrm{B} 4.2-4.6 \mathrm{~mm})$ were found 

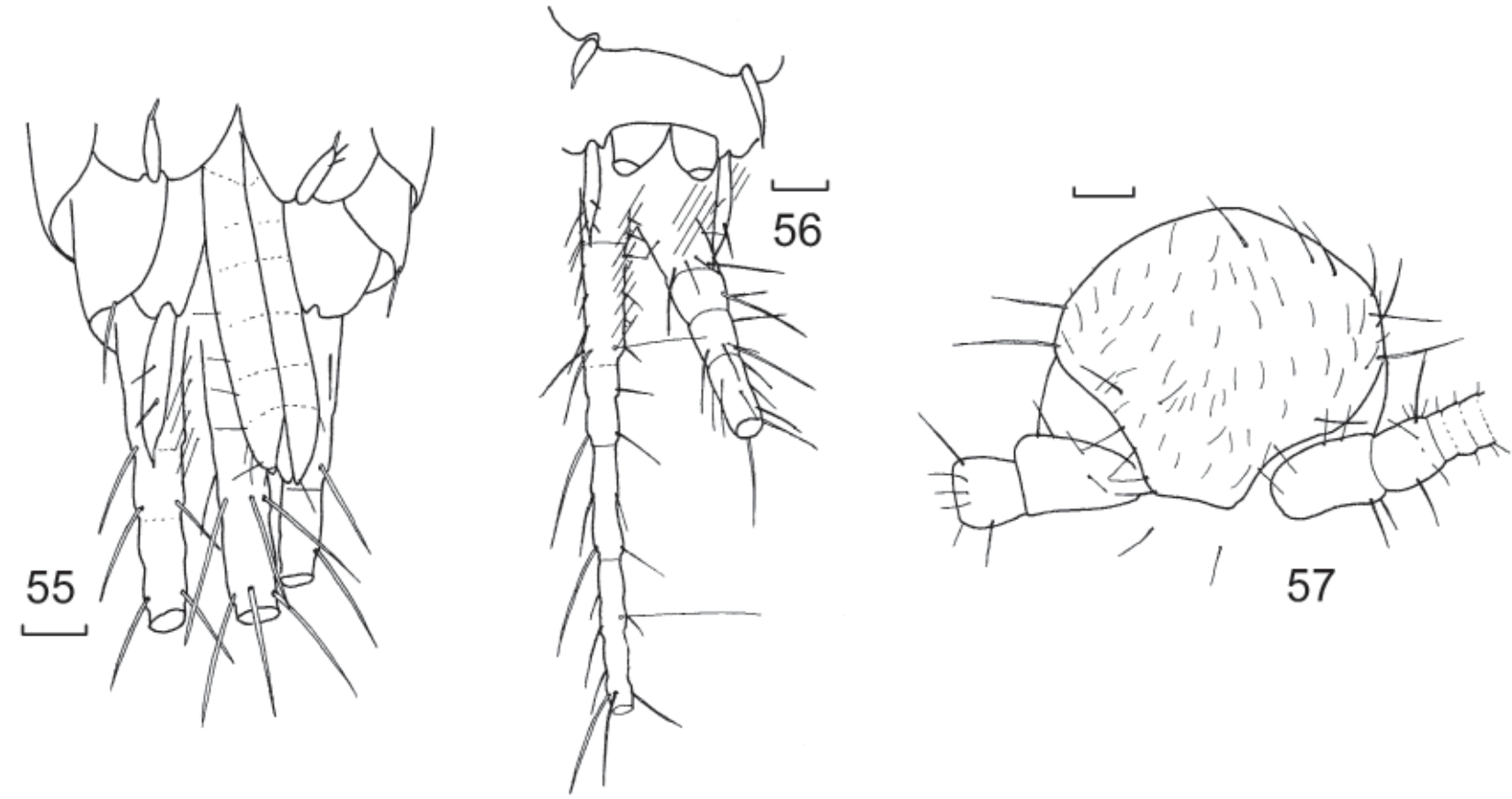

FIGURES 55-57 Trinemura sp.: 55, genital area of $q$; 56, genital area of $\delta$ (cross-hatched area at least partially obscured by dirt); 57 , head. All scale bars $0.1 \mathrm{~mm}$.

in the same tube as a specimen of Trinemura cundalinae (WAM E82697). While originally assumed to be juveniles, examination revealed that the female, with a HW of only 0.53 had a well developed ovipositor (Figure 55), stout and extending slightly beyond the apices of stylet IX, pseudo-segmented with about 6 articles. By comparison females of Trinemura cundalinae with HW 0.73 did not show any significant ovipositor development. The two males, with HW of 0.50 and 0.65 did not however show any secondary sexual character development on either the terminal filaments (Figure 56) nor the pedicel (Figure 57) and hence no reliable diagnostic features and will not be described here. They differ from males of both Trinemura cundalinae and $T$. callawae by having parameres that extend beyond the apices of the internal process of coxite IX by about half their length; some setae at the base of the cerci appear to be very slightly thicker however the visibility was obscured by accumulations of dirt in this region. It is possible that males of this species develop secondary sexual characteristics much later than the females begin to mature. However in other Australian species of Nicoletiidae the secondary sexual characters are usually apparent in males of the same size as females with such a well developed ovipositor.

\section{DISCUSSION}

\section{MORPHOLOGY}

Large size is a common phenomenon among cave adapted insects. At 10.7 and $10.9 \mathrm{~mm}$, respectively,
Trinemura callawae and T. cundalinae are larger than any other described Australian Nicoletiidae species (previous largest Subtrinemura excelsa at $9.4 \mathrm{~mm}$, an endogean species) but are still significantly smaller than other species described from limestone caves in Mexico (e.g. up to $29 \mathrm{~mm}$ in Squamigera latebricola Espinasa, 1999; see Espinasa and Burnham 2004), the United States (e.g. up to $20 \mathrm{~mm}$ in Texoreddellia aquilonalis Espinasa and Giribet, 2009) and Europe (e.g. up to $22.4 \mathrm{~mm}$ in Squamatinia algharbica Mendes and Reboleira, 2012 in Reboleira et al. 2012). T. callawae and $T$. cundalinae can easily be distinguished from other described Trinemura by the presence of an apophysis on the scape (also seen in Subtrinemura anemone).

It is opportune to note here that we have examined and recognised additional species of small sized Trinemura collected from subterranean habitats at several other locations in the Pilbara, which are awaiting description. One picture emerging is that there appears to be two different groups within hypogean Trinemura. One is represented by these larger species with apophyses on the pedicella and a second group of smaller species where the pedicel is expanded but lacks apophyses. The secondary sexual characters on the terminal filaments become important in describing these smaller species.

\section{MOLECULAR ANALYSIS}

Sequence divergence calculated among haplotypes showed little divergence between the $T$. callawae haplotypes $(0.3$ to $0.9 \%)$, but the $T$. cundalinae haplotype differed from those at Callawa by 6.2 to $6.5 \%$. T. callawae and T. cundalinae appear to share a common 
ancestor in the Pilbara based on a phylogenetic analysis (not shown), but given the slower rate of evolution in 12S compared to COXI (Mueller 2006), the level of sequence divergence suggests that the two lineages have been isolated from one another for perhaps two million years or more. The molecular data has quantified the degree of genetic divergence between these two species, which are well differentiated on morphological characters in mature males. When mature male specimens are not available, or their diagnostic appendages have been damaged or lost as often the case with these fragile animals, we suggest that $12 \mathrm{~S}$ sequence divergences will prove to be a useful taxonomic tool.

\section{BIOLOGY}

The two described species, with their large size and elongate appendages are clearly troglobites specialized for a subterranean existence. Morphometric data suggests the third smaller, undescribed species has only a moderate degree of troglomorphy. The longest preserved cerci was $>\mathrm{H}+\mathrm{B}$ but the $\mathrm{L} / \mathrm{W}$ ratio of tibia and tarsi, while more elongate than the soil-dwelling T. novaehollandiae Silvestri, 1908 and T. calcaripalpa Smith, 1998 are more in line with those of the soildwelling T. watsoni Smith, 1998 and less elongate than the cave dwelling T. troglophila from North West Cape.

\section{HABITAT}

As part of the environmental assessment for the Goldsworthy Iron Ore Mining Operation (Environmental Protection Authority 2009), BHP Billiton (2008) assessed the geology of the Callawa and Cundaline ridges in relation to providing subterranean habitat. While the host rocks are mostly fine grained and dense banded-iron formation, belonging to the Nimingarra Iron Formation, ore-forming weathering processes have altered the porosity to form voids and cavities, usually measured on a scale of fractions of a millimetre although occasional larger (centimetre or less commonly on a metre scale) voids occur. Faulting has also contributed to the development of secondary porosity in otherwise non-porous rock. Drill records show that cavities extend throughout the Nimingarra Formation to depths of 160 metres (m), however cavities are more prevalent at shallower depths (BHP Billiton 2008).

Drill holes intersect the entire vertical profile of potential habitat, creating an artificial conduit enabling terrestrial invertebrates to migrate up and down the hole, so the depths at which traps are placed in drill holes (typically $20 \mathrm{~m}$ ) cannot be used to infer the depth of habitat. A perched local water table lies between 60 and $120 \mathrm{~m}$ below the surface of the ridges (Subterranean Ecology unpublished data) indicating the potential depth of unsaturated cavernous habitat available for air-breathing subterranean invertebrates. The existence of deep subterranean habitats on the Callawa and Cundaline ridges is further confirmed by net haul sampling undertaken below the water table (i.e. $>60 \mathrm{~m}$ below surface) which detected several species of aquatic subterranean invertebrates (Karanovic et al. 2011; Subterranean Ecology 2008b).

\section{DISTRIBUTION PATTERNS}

Trinemura callawae and T. cundalinae each appear to be endemic to the respective landforms after which they are named. The known distribution range of $T$. callawae is confined to the area of exploration drill holes sampled in the northeast quarter of Callawa ridge, an area of approximately three $\mathrm{km}^{2}$. In the absence of any obvious habitat discontinuities we infer that the range of T. callawae is likely to extend throughout the continuous outcrop of Nimingarra Iron Formation comprising Callawa ridge, an area of approximately $17 \mathrm{~km}^{2}$ (Figure 2 ). The sampled distribution range of $T$. cundalinae spans an area of approximately $6 \mathrm{~km}^{2}$ on Cundaline ridge. On Cundaline-Mundrayina ridges the area of contiguous Nimingarra Formation covers $21 \mathrm{~km}^{2}$ with no obvious geo-topographic barriers that might limit the dispersal and distribution of subterranean fauna.

The Cundaline-Mundrayina iron formation is topographically isolated from the Callawa iron formation by the alluvial valley and plain occupied by Eel Creek. The alluvial plain is about $2 \mathrm{~km}$ wide at the narrowest point between the iron formations (Figure $2,3)$. The plain consists of a veneer of fine-grained alluvial sediments overlying granitoid rocks. The shallow depth to watertable (c. $<10 \mathrm{~m}$ ) would limit the depth of unsaturated subterranean habitat available for air breathing troglofauna, and while the alluvium could be expected to have reasonable primary porosity its unconsolidated texture would preclude the development of secondary porosity which provides the habitat within the iron formations. Accordingly we suggest that the alluvial plain presents a phylogeographic barrier to the dispersal of Trinemura.

Trinemura callawae and T. cundalinae meet the criteria of short range endemic species. Harvey (2002) suggested a nominal distribution range of less than 10,000 square kilometres as a working definition for SRE species, although Eberhard et al.. (2009) recommended a smaller area of less than 1,000 square kilometres for stygofauna. Many SRE species have even smaller ranges and our observations for Trinemura are consistent with the distribution patterns documented in other groups of Pilbara troglobites, most notably in the Robe Valley where pseudoscorpions (Edward and Harvey 2008) and schizomids are known to be endemic to individual geological formations such as pisolitic mesas only a few hundred hectares in area (Harvey et al. 2008). The iron formation ridges at Yarrie present a similar physiography to the pisolitic mesas in the Robe Valley, albeit the Yarrie landforms are slightly larger in scale. A series of twelve geo-topographically isolated iron formation ridges extends from Callawa ridge in the south to Nimingarra ridge in the north, a distance of $60 \mathrm{~km}$. We consider it probable that additional locally endemic species of Trinemura, and other troglobites (including beetles, cockroaches, diplurans, 
diplopods, arachnids and isopods) will occur in other iron formation ridges which remain to be surveyed for troglofauna.

\section{CONCLUSION}

The surveyed distributions of the species appears confined to proximal landforms which are topographically and geologically isolated from each other. Molecular genetic evidence (12S) supports the morphological definition and phylogeographic separation. These and other Australian troglobitic nicoletiids are short range endemic species which may be vulnerable to habitat loss, habitat degradation, and climate change.

\section{ACKNOWLEDGEMENTS}

Subterranean Ecology and Terrie Finston acknowledge BHP Billiton Iron Ore for funding the survey and sequencing work at Goldsworthy Iron Ore Mining Operation.

\section{REFERENCES}

BHP Billiton (2008). Cundaline and Callawa Geological Review. Unpublished report prepared by BHP Billiton Iron Ore, $22^{\text {nd }}$ September 2008, 14 pp. Provided as attachment in Subterranean Ecology (2008a).

Bureau of Meteorology (1977). Climatic Atlas of Australia. Australian Government Publishing Service: Canberra.

Camacho, A.I. (1992). A classification of the aquatic and terrestrial subterranean environment and their associated fauna (pp. 57-103) In: Camacho, A.I. (ed.), The natural history of biospeleology. Monografias Museo Nacional de Ciencias Naturales. Graficas: Madrid.

Eberhard, S.M., Halse, S.A. and Humphreys, W.F. (2005). Stygofauna in the Pilbara region, north-west Western Australia: a review. Journal of the Royal Society of Western Australia 88(4): 167-176.

Eberhard, S.M., Halse, S.A., Williams, M., Scanlon, M.D., Cocking, J.S., and Barron, H.J. (2009). Exploring the relationship between sampling efficiency and short range endemism for groundwater fauna in the Pilbara region, Western Australia. Freshwater Biology 54: 885-901.

Edward, K.L. and Harvey, M.S. (2008). Short-range endemism in hypogean environments: the pseudoscorpion genera Tyrannochthonius and Lagynochthonius (Pseudoscorpiones: Chthoniidae) in the semiarid zone of Western Australia. Invertebrate Systematics 22: 259-293.

Environment Australia (2000). Revision of the Interim Biogeographic Regionalisation for Australia (IBRA) and development of version 5.1 - Summary report. 37. Environment Australia: Canberra.

Environmental Protection Authority (EPA) (2007). Sampling methods and survey considerations for subterranean fauna in Western Australia Guidance Statement 54A (Draft) Technical Appendix to Guidance Statement No. 54. Environmental Protection Authority, Perth.

Environmental Protection Authority (EPA) (2009). Cundaline and Callawa Mining Operations - Report and recommendations of the Environmental Protection
Authority, Perth Western Australia. Report 1338, September 2009.

Espinasa, L. and Burnham, B. (2004). Revision of the genus Squamigera (Insecta: Zygentoma: Nicoletiidae) with descriptions of two new species. Proceedings of the Biological Society of Washington. 117(4): 582-593.

Espinasa, L. and Giribet, G. (2009). Living in the dark - the taxonomic status, phylogeography and dispersal capabilities of the nicoletiid genus Texoreddellia Wygodzinsky, 1973 (Hexapoda, Zygentoma, Nicoletiidae) in Texas and Mexico). Texas Memorial Museum Speleological Monographs 7(V): $87-110$.

Gentilli, J. (1972). Australian climate patterns. Thomas Nelson and Sons: Melbourne.

Gibert, J. and Deharveng, L. (2002). Subterranean ecosystems: a truncated functional biodiversity. Bioscience 52(6): 473-481.

Guzik, M.T., Austin, A.D., Cooper, S., Harvey, M., Humphreys, W.F., Bradford, T., Eberhard, S., King, R.A., Leys, R., Muirhead, K.A. and Tomlinson, M. (2010). Is the Australian subterranean fauna uniquely diverse? Invertebrate Systematics 24: 407-418.

Harvey, M.S. (2002). Short-range endemism among the Australian fauna: some examples from non-marine environments. Invertebrate Systematics 16: 555-570.

Harvey, M.S., Berry, O., Edward, K.L. and Humphreys G. (2008). Molecular and morphological systematics of hypogean schizomids (Schizomida: Hubbardiidae) in semiarid Australia. Invertebrate Systematics 22: 167-194.

Harvey, M.S., Rix, M.G., Framenau, V.W., Hamilton, Z., Johnson, M.S., Teale, R., Humphreys, G., Humphreys, W.F. (2011). Protecting the innocent: studying short-range endemic taxa enhances conservation outcomes. Invertebrate Systematics 25: 1-10.

Humphreys, W.F. (2008). Rising from Down Under: developments in subterranean biodiversity in Australia from a groundwater fauna perspective. Invertebrate Systematics 22: $85-101$.

Karanovic, T., Eberhard, S.M., and Murdoch, A. (2011). A cladistic analysis and taxonomic revision of Australian Metacyclops and Goniocyclops, with description of four new species and three new genera (Copepoda, Cyclopoida). Crustaceana 84(1): 1-67.

Mendes, L.F. (1994). Evolutionary relationships among the Nicoletiidae (Insecta, Zygentoma). Acta Zoologica Fennica 195: 98-103.

Mueller, R.L. (2006). Evolutionary rates, divergence dates and the performance of mitochondrial genes in Bayesian Phylogenetic analysis. Systematic Biology 55: 289-300.

Picchi, V.D. (1972). Parthogenic reproduction in the silverfish Nicoletia meinerti (Thysanura). Journal of the New York Entomological Society 80(1): 2-4.

Reboleira, A.P.S., Gonçalves, F., Oromi, P. and Mendes, L.F. (2012). On a remarkable new Coletiniinae collected from caves in South Portugal (Zygentoma: Nicoletiidae). Zootaxa 3260: $33-46$.

Silvestri, F. (1908). Thysanura. In: Michaelsen, W. and Hartmeyer, R. (eds), Die Fauna Südwest-Australiens. Ergebnisse der Hamburger südwestaustralischen Forschungsreise 1905. Vol. 2: 47-68. Gustav Fischer: Jena.

Simon, C., Fratl, F., Beckenbach, A., Crespi, B., Liu, H., Flook, P. (1994). Evolution, weighting, and phylogenetic utility of mitochondrial gene sequences and a compilation of 
conserved polymerase chain reaction primers. Annals of the Entomological Society 87: 651-701.

Smith, G.B. (1998). Review of the Australian Nicoletiinae (Zygentoma: Nicoletiidae). Invertebrate Taxonomy 12: 135-189.

Smith, G.B. (2006). New species of Metrinura Mendes (Zygentoma: Nicoletiidae) from Queensland, Australia. Australian Journal of Entomology 45: 163-167.

Subterranean Ecology (2008a). Goldsworthy Mining Operations, Cundaline and Callawa Mining Operations Troglofauna assessment. Unpublished report to BHP Billiton.

Subterranean Ecology (2008b). Goldsworthy Mining Operations, Cundaline and Callawa Mining Operations Stygofauna assessment. Unpublished report to BHP Billiton.
Subterranean Ecology (2009). Cundaline and Callawa Mining Operations additional targeted troglofauna surveys. Unpublished report to BHP Billiton.

Thompson, J., Higgins, D., and Gibson, T. (1994). CLUSTAL $\mathrm{W}$ : improving the sensitivity of progressive multiple sequence alignment through sequence weighting, positionspecific gap penalties and weight matrix choice. Nucleic Acids Research 22: 4673-4680. doi:10.1093/nar/ 22.22.4673

Trajano, E. (2005). Evolution of lineages. In: Culver, D.C. and White, W.B. (eds), Encyclopaedia of caves: pp. 230-234. Elsevier.

Williams, I.R. (2003) Yarrie, W.A. (3rd Edition): Western Australia Geological Survey, 1:250,000 Geological Series Explanatory Notes, $84 \mathrm{pp}$.

MANUSCRIPT RECEIVED 20 JANUARY 2012; ACCEPTED 22 AUGUST 2012. 